\title{
The potential risk of enzootic Trypanosoma cruzi transmission inside four training and re-training military battalions (BITER) in Colombia
}

Omar Cantillo-Barraza', Jeffer Torres', Carolina Hernández²,3, Yanira Romero', Sara Zuluaga4, Camilo A. Correa-Cárdenas ${ }^{1}$, Giovanny Herrera², Omaira Rodríguez" ${ }^{1}$ María Teresa Alvarado', Juan David Ramírez ${ }^{2}$ and Claudia Méndez ${ }^{1 *}$ (D)

\begin{abstract}
Background: Colombia's National Army is one of the largest military institutions in the country based on the number of serving members and its presence throughout the country. There have been reports of cases of acute or chronic cases of Chagas disease among active military personnel. These may be the result of military-associated activities performed in jungles and other endemic areas or the consequence of exposure to Trypanosoma cruzi inside military establishments/facilities located in endemic areas. The aim of the present study was to describe the circulation of $T$. cruzi inside facilities housing four training and re-training battalions [Battalions of Instruction, Training en Re-training (BITERs)] located in municipalities with historical reports of triatomine bugs and Chagas disease cases. An entomological and faunal survey of domestic and sylvatic environments was conducted inside each of these military facilities.
\end{abstract}

Methods: Infection in working and stray dogs present in each BITER location was determined using serological and molecular tools, and T. cruzi in mammal and triatomine bug samples was determined by PCR assay. The PCR products of the vertebrate $12 S$ rRNA gene were also obtained and subjected to Sanger sequencing to identify blood-feeding sources. Finally, we performed a geospatial analysis to evaluate the coexistence of infected triatomines and mammals with the military personal inside of each BITER installation.

Results: In total, 86 specimens were collected: 82 Rhodnius pallescens, two Rhodnius prolixus, one Triatoma dimidiata and one Triatoma maculata. The overall T. cruzi infection rate for R. pallescens and R. prolixus was 56.1 and 100\% respectively, while T. dimidiata and T. maculata were not infected. Eight feeding sources were found for the infected triatomines, with opossum and humans being the most frequent sources of feeding (85.7\%). Infection was most common in the common opossum Didelphis marsupialis, with infection levels of $77.7 \%$. Sylvatic Tcl was the most frequent genotype, found in $80 \%$ of triatomines and $75 \%$ of D. marsupialis. Of the samples collected from dogs $(n=52)$, five (9.6\%; 95\% confidence interval: 3.20-21.03) were seropositive based on two independent tests. Four of these dogs

\footnotetext{
*Correspondence: claudiamendez11@gmail.com

${ }^{1}$ Grupo de Investigación en Enfermedades Tropicales del Ejército

(GINETEJ), Laboratorio de Referencia E Investigación, Dirección de Sanidad Ejército, Bogotaá, Colombia

Full list of author information is available at the end of the article
} permits use, sharing, adaptation, distribution and reproduction in any medium or format, as long as you give appropriate credit to the original author(s) and the source, provide a link to the Creative Commons licence, and indicate if changes were made. The images or other third party material in this article are included in the article's Creative Commons licence, unless indicated otherwise in a credit line to the material. If material is not included in the article's Creative Commons licence and your intended use is not permitted by statutory regulation or exceeds the permitted use, you will need to obtain permission directly from the copyright holder. To view a copy of this licence, visit http://creativecommons.org/licenses/by/4.0/. The Creative Commons Public Domain Dedication waiver (http://creativeco mmons.org/publicdomain/zero/1.0/) applies to the data made available in this article, unless otherwise stated in a credit line to the data. 
were creole and one was a working dog. The spatial analysis revealed a sympatry between infected vectors and mammals with the military population.

Conclusions: We have shown a potential risk of spillover of sylvatic T. cruzi transmission to humans by oral and vectorial transmission in two BITER installations in Colombia. The results indicate that installations where 100,000 active military personnel carry out training activities should be prioritized for epidemiological surveillance of Chagas disease.

Keywords: Chagas disease, Trypanosoma cruzi, Colombia, Colombian National Army, Non-domiciliated triatomines, Rhodnius pallescens, Rhodnius prolixus, Entomological and mammal surveillance, Reservoirs, Didelphis marsupialis

\section{Background}

Chagas disease (CD) caused by the parasite Trypanosoma cruzi, affects about six million people in Latin America [1], and it has been estimated that $1.67-2 \%$ of the population of Colombia are infected with this parasite [2]. Trypanosoma cruzi is transmitted to humans mainly by triatomine vectors (Hemiptera: Reduviidae) through contact of the skin and mucous membranes with feces and other secretions of infected insects [3]. However, this parasite may be also transmitted by blood transfusion, congenitally, organ transplantation, laboratory accidents and ingestion of food/drinks contaminated with T. cruzi [4].

Trypanosoma cruzi is a hemotropic protozoan that infects around 158 mammalian species. It exhibits broad intraspecific genetic diversity and is categorized into at least six discrete typing units (DTUs) [5, 6], one of which, TcBat, is an emerging genotype. Trypanosoma cruzi DTU I (TCI) is the most prevalent DTU in the region north of the Amazon basin, and it can be further subdivided into two major genotypes, namely domestic $\left(\mathrm{TcI}_{\mathrm{Dom}}\right)$ and sylvatic $\left(\operatorname{TcI}_{\text {Sylvatic }}\right)[7,8]$. The former is generally associated with the domestic transmission cycle in specific areas, and the latter is frequently involved in enzootic transmission and oral outbreaks $[9,10]$.

Domestic transmission by domiciliated species of the Triatoma and Rhodnius genera has traditionally been responsible for higher transmission rates of $C D$ in areas of high economic and social deprivation in Central and South America [11-14]. However, following the systematic control of $\mathrm{CD}$ intradomestic vectors in Brazil, Argentina, Paraguay, Chile, Guatemala, Nicaragua and Colombia, newer scenarios mediated by non-domiciled triatomines have come to the fore in terms of $T$. cruzi transmission dynamics [15-25]. In these scenarios, new cases occurr more commonly in residents of relatively older age, and T. cruzi transmission is associated with environmental and ecological characteristics mediated by reinfestation of peridomestic native species of triatomines. In addition, there have been outbreaks due to oral transmission in places where sylvatic triatomines invade houses and where there is a positive selection of generalist species with high competence as reservoirs [17,
26-29]. The development of fishing, hunting and agricultural activities that bring people closer to the enzootic cycle $[16,30,31]$ and working, educational and social activities where people share the same food increase the risk of spillover of enzootic transmission to humans [32].

Colombia's National Army has approximately 400,000 soldiers and is the largest military institution in terms of manpower in Colombia. The soldiers actively protect Colombia's sovereignty in border areas and patrol and maintain public order in all municipalities, including those with enzootic transmission of $T$. cruzi. Acute cases of $C D$ related to vectorial and oral transmission as well as chronic cases among active military personnel in military installations are usually reported in the National Public Health Surveillance System (SIVIGILA) [33-35]. A recent study of T. cruzi infection among the active military population found that around $70.5 \%$ of the evaluated population were born in municipalities that have reported infected triatomines [35-37]. In this context, it is possible that military personnel exposed to different scenarios of $\mathrm{CD}$ transmission could converge in battalions or cantonment centers, combined with the existence of triatomines bugs and reservoirs. This scenario could result in a potential risk of transmission inside military establishments, but to date there has been no study on this potential scenario.

Battalions of Instruction, Training en Re-training (BITERs: acronym in Spanish) are an essential military establishment within the organizational structure of Colombia's National Army. In these units, many professional soldiers congregate for training activities, which also include the initial training for recently drafted recruits as part of the mandatory military service in Colombia. Due to the epidemiological relevance of BITERs in terms of T. cruzi infection spillover, the aim of this study was to evaluate the potential of T. cruzi transmission inside four BITER units located in endemic areas of Colombia.

\section{Methods}

\section{Study area}

This study was carried out between October 2019 and March 2020 in four BITERs located in four 
endemics municipalities: BITER 16, Yopal $\left(5^{\circ} 29^{\prime} 31^{\prime \prime} \mathrm{N}\right.$, $\left.73^{\circ} 29^{\prime} 12^{\prime \prime} \mathrm{W}\right)$ in the department of Casanare; BITER 17 , Carepa $\left(5^{\circ} 19^{\prime} 50^{\prime \prime} \mathrm{N}, 72^{\circ} 23^{\prime} 26^{\prime \prime} \mathrm{W}\right)$ in the department of Antioquia; BITER 5, Aguachica $\left(8^{\circ} 11^{\prime} 46^{\prime \prime} \mathrm{N}\right.$, $\left.73^{\circ} 36^{\prime} 47.32^{\prime \prime} \mathrm{W}\right)$ and BITER 10, La Loma $\left(9^{\circ} 35^{\prime} 43.98^{\prime \prime} \mathrm{N}\right.$, $\left.73^{\circ} 26^{\prime} 42.38^{\prime \prime} \mathrm{W}\right)$ both in the department of Cesar (Fig. 1). These BITERs receive different units of the National Army that are gathered together in each department for training and re-training activities and consist of around 2,500 Army members that inhabit each military installation, carrying out camping activities and receiving food rations prepared inside the battalion.

\section{Insect collection}

The entomological study was designed to gather samples in different tropical seasons (rainy and dry). Sample collection during the rainy season was conducted between

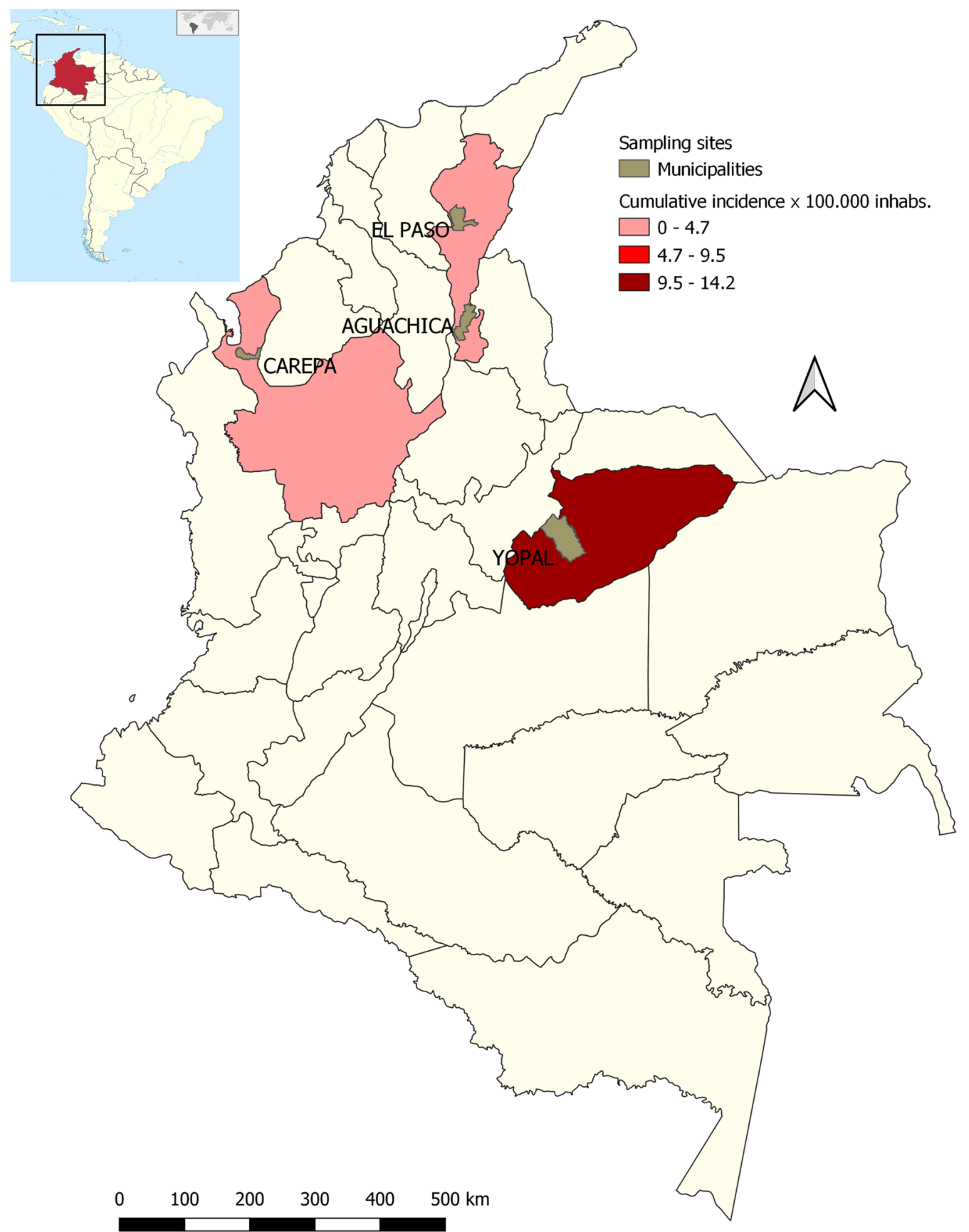

Fig. 1 Map showing the locations (3 departments) of the four BITERs of the Colombia National Army that were sampled between 2019 and 2020 
October and November 2019, and during the dry season samples were collected from February to March 2020. Searches for triatomine insects were carried inside bedrooms and lodgings with permission and cooperation of the soldiers and military and governmental officials. We also examined all palms of Attalea butyracea species located $<10 \mathrm{~m}$ distance from bedrooms, lodgings and kitchens of each BITER for triatomines following the methodology described by Romaña [38]. Dry and green leaves, organic debris, interfoliaceous meshes and bracts were examined for the presence of triatomines with the help of a ladder. Collected bugs were transported to the BCEI laboratory (University of Antioquia), registered and identified using taxonomic keys [39].

\section{Molecular detection of $T$. cruzi}

Total DNA was extracted from $200 \mu \mathrm{l}$ of the reservoir host's blood, hemoculture of mammals and feces of collected triatomines, using a genomic DNA purification kit (Invisorb ${ }^{\circledR}$ Spin Universal Kit; STRATEC Molecular $\mathrm{GmbH}$, Berlin, Germany). Trypanosoma cruzi infection was detected by conventional PCR (cPCR) in a total volume of $25 \mu \mathrm{l}$ containing 40-50 ng of genomic DNA previously quantified using a BioDrop uLite Spectrophotometer (Biochrom US Inc., Holliston, MA, USA), $1 \times$ of buffer, $0.04 \mathrm{mM}$ of dNTP, $1.5 \mathrm{mM} \mathrm{MgCl}_{2}, 0.4 \mu \mathrm{M}$ of TCZ1 (5'-GCTCTTGCCCACA(AC)GGGTGC-3') and TCZ2 (5'-CCAAGCAGCGGATAGTTCAGG-3') primers [40-43] and $0.05 \mathrm{U}$ of Taq polymerase (Invitrogen, Fisher Thermo Scientific, Waltham, MA, USA). The thermal cycling conditions for amplification of a 188-bp fragment of satellite DNA (SatDNA) were: pre-heating at $95{ }^{\circ} \mathrm{C}$ for $15 \mathrm{~min}$; followed by 40 cycles at $95^{\circ} \mathrm{C}$ for $10 \mathrm{~s}$, $55{ }^{\circ} \mathrm{C}$ for $15 \mathrm{~s}$ and $72{ }^{\circ} \mathrm{C}$ for $10 \mathrm{~s}$; and then a final extension of $72{ }^{\circ} \mathrm{C}$ for $10 \mathrm{~min}$ [41]. The amplification products were electrophoresed in a $1.5 \%$ agarose gel, stained with SYBR Safe DNA Gel Stain and visualized under UV light using the molecular imager ${ }^{\circledR}$ Gel DOC $^{\mathrm{TM}} \mathrm{XR}+$ with Image $\mathrm{Lab}^{\mathrm{TM}}$ software (Bio-Rad Laboratories Inc., Hercules, CA, USA).

\section{Genotyping}

In positive samples with T. cruzi infection, PCR was performed using three different molecular markers to detect the six DTUs and the two types of TcI $\left(\mathrm{TcI}_{\text {Dom }}\right.$ and $\mathrm{TcI}_{\text {Sylvatic }}$ ). The molecular markers amplified by PCR were two regions of the intergenic miniexon-gene (SL-IR) and ribosomal DNA (rDNA) 24S $\alpha$ [42, 44, 45]. Green Master Mix GoTaq ${ }^{\circledR}$ (Promega, Madison, WI, USA) was used for amplification of these three targets. All reaction volumes contained $12.5 \mu \mathrm{l}$ of Master Mix GoTaq ${ }^{\circledR}$ Green, $10 \mu \mathrm{M}$ of each primer and $5 \mu \mathrm{l}$ of DNA to which water was added to a final reaction volume of $25 \mu$ l. Primers and
PCR conditions can given in Additional file 1: Appendix S1. Amplification products were electrophesed in a $1.5 \%$ agarose gel, stained with SYBR Safe DNA Gel Stain and visualized under UV light using the molecular imager ${ }^{\circledR}$ Gel $\mathrm{DOC}^{\mathrm{TM}} \mathrm{XR}+$ and Image $\mathrm{Lab}^{\mathrm{TM}}$ software (Bio-Rad Laboratories Inc.) based on the sizes of amplicons in each PCR according to the algorithm (Additional file 2: Figure S1) [42].

Samples of the DTU TcI were classified into $\mathrm{TcI}_{\text {Dom }}$ and $\mathrm{TcI}_{\text {Sylvatic }}$ genotypes. The reaction mixture consisted of $1 \times$ Taq polymerase amplification buffer $(100 \mathrm{mM}$ Tris-HCl, pH 8.3; Invitrogen, Thermo Fisher Scientific), $100 \mathrm{mM}$ deoxynucleoside triphosphate solution, $25 \mathrm{mM}$ $\mathrm{MgCl}_{2}$ solution, $5 \mathrm{U} / \mu \mathrm{l}$ of Taq polymerase platinum (Invitrogen, Thermo Fisher Scientific), $50 \mathrm{pM}$ of T. cruzi mini-exon primers 1Am (5'-TGTGTGTGTATGTATGTG $\left.-3^{\prime}\right)$ and $1 \mathrm{~B}\left(5^{\prime}-\right.$ CGGAGCGGTGTGTGCAG-3') [46]. The thermal cycling profile consisted of an initial denaturation of $94{ }^{\circ} \mathrm{C}$ for $4 \mathrm{~min}$; followed by 35 cycles of $94^{\circ}$ for $30 \mathrm{~s}, 55^{\circ} \mathrm{C}$ for $20 \mathrm{~s}$ and $72{ }^{\circ} \mathrm{C}$ for $20 \mathrm{~s}$; and then a final extension of $72{ }^{\circ} \mathrm{C}$ for $10 \mathrm{~min}[9,47]$. Seven strains were used as positive controls: $\mathrm{MHOM} / \mathrm{CO} / 01 / \mathrm{DA}\left(\mathrm{TcI}_{\text {Dom }}\right)$,

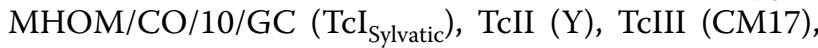
TcIV (YLY), TcV (V) and TcVI (CLBrener).

\section{Blood-meal sources}

Blood-meal sources in all T. cruzi-positive triatomines were identified by PCR products of the vertebrate $12 \mathrm{~S}$ rRNA gene, which were obtained through amplification of a 215-bp fragment using primers L1085 (5'-CCCAAA CTGGGATTAGATACCC-3') and H1259 (5'-GTTTGC TGAAGATGGCGGTA-3') [48]. All reaction volumes contained $12.5 \mu \mathrm{l}$ of Master Mix GoTaq ${ }^{\circledR}$ Green, $10 \mu \mathrm{M}$ of each primer and $5 \mu \mathrm{l}$ of DNA to which water was added to a final reaction volume of $25 \mu \mathrm{l}$. The thermal cycling profile consisted of an initial denaturation of $94{ }^{\circ} \mathrm{C}$ for $4 \mathrm{~min}$; followed by 35 cycles of $94^{\circ}$ for $30 \mathrm{~s}, 57^{\circ} \mathrm{C}$ for $15 \mathrm{~s}$ and $72{ }^{\circ} \mathrm{C}$ for $30 \mathrm{~s}$; and a final extension of $72{ }^{\circ} \mathrm{C}$ for $10 \mathrm{~min}$. Amplification products were electrophoresed in a $1.5 \%$ agarose gel, stained with SYBR SafeDNA Gel Stain and visualized under UV light using the molecular imager ${ }^{\circledR}$ Gel $\mathrm{DOC}^{\mathrm{TM}} \mathrm{XR}+$ with Image Lab ${ }^{\mathrm{TM}}$ software (Bio-Rad Laboratories Inc.). The PCR products were cleaned using ExoSAP-IT ${ }^{\circledR}$ Express PCR Product Cleanup 75001/75002 (Affimetrix, Thermo Fisher Scientific) and then submitted to Macrogen Korea (Seoul, South Korea) for Sanger sequencing (terminal dideoxy method) using the BigDye $^{\mathrm{TM}}$ Terminator v3.1 Cycle Sequencing Kit with an AB3730xI automatic sequencer. The resulting sequences in both directions were edited in MEGA X software [49], assembled and checked by eye for all base changes according to the quality of peaks (height, not overlapping and evenly spaced) prior to be submitted to the 
bsic local alignment search tool for nucleotide databases (BLASTn) of the National Center for Biotechnology Information (NCBI; https://blast.ncbi.nlm.nih.gov) for similarity search, defining each species with percentage identity $>92 \%$ and e-value close to 0.00 . All new genetic sequences of $12 S$ rRNA derived from the blood-meal source analysis were deposited and are available in GenBank (https:// www.ncbi.nlm.nih.gov/genbank/) under accession numbers OK040172 - OK040196 and OK058390 - OK058403.

\section{Survey of wild hosts and detection of $T$. cruzi in small mammals}

Small mammals were captured using traps (Tomahawk ${ }^{\circledR}$ and Sherman ${ }^{\circledR}$ traps) baited with a mixture of peanuts, bananas, oats and fish. At each BITER, traps were set for 5 nights near sampled palm trees and placed in locations where there had been previous sightings of mammals. The traps were distributed along linear transects, with capture points established $20 \mathrm{~m}$ apart from each other. Additionally, mammals present in the palms during wild triatomine collection were captured and anesthetized $(50 \mathrm{mg} / \mathrm{kg}$ body weight of ketamine, administered by intramuscular injection), and blood samples were collected and stored for DNA extraction and molecular diagnosis. Also, two tubes containing Novy-MacNealNicolle medium medium covered with an liver infusion tryptose (LIT) overlay were inoculated with $0.3-0.6 \mathrm{~m}$ of blood. These tubes were examined once weekly for 3 months for the presence of Trypanosoma spp.

\section{Blood sampling and serological diagnostic tests in dogs}

Fifty-two dogs (Canis lupus familiaris), including 33 military working dogs and 19 creoles, were studied in the four BITERs. For each animal, two 5-ml blood samples were collected from the radial vein into serum and EDTA.K3 vacutainers and stored at $4{ }^{\circ} \mathrm{C}$ until processed. For serum extraction, samples were centrifuged at 5000 $g$ for $10 \mathrm{~min}$ for separation, and the serum was stored at $-20^{\circ} \mathrm{C}$ until serological assays were performed. Genomic DNA was extracted from $200 \mu \mathrm{l}$ of blood from the EDTA. K3 vacutainer using the Genomic DNA Purification Kit (DNeasy Blood \& Tissue Kit; Qiagen, Hilden, Germany) according to the manufacturer's instructions. Total DNA was diluted with $100 \mu$ l elution buffer and stored at -20 ${ }^{\circ} \mathrm{C}$ until molecular diagnosis, as mentioned above.

Anti-T. cruzi antibodies (immunoglobulin G [IgG]) in dogs were detected using an enzyme-linked immunosorbent assay (ELISA) and an indirect immunofluorescence antibody test (IFAT). For both techniques, the antigen was prepared from harvested epimastigotes of $T$. cruzi Colombian strains (I.RHO/CO/00/CAS-15.CAS; I. TRI/CO/03/MG-8.MAG), previously characterized as TcI [42]. For the ELISA, a whole lysate extracted from epimastigotes was used as antigen, while for IFAT, antigen was obtained from complete epimastigotes fixed in $1 \%$ formaldehyde as reported elsewhere [50]. The detection cutoff was determined as optical absorbance $\geq 0.200$ (mean \pm standard deviation [SD] of negative control) for the ELISA and sera dilution of $\geq 1 / 40$ for the IFAT, as reported elsewhere [28]. Animals were defined as positive for anti-T. cruzi antibodies when the samples were reactive to both tests; the ELISA and IFAT used by BioManguinhos/Fiocruz (Rio de Janeiro, RJ, Brazil) have a $100 \%$ sensitivity and $98.7 \%$ specificity [28]. Cross-reactions and/or mixed infections of T. cruzi and Leishmania spp. in serum were also assayed using antigens derived from a mixture of Leishmania infantum and Leishmania panamensis using IFAT. The IFAT cutoff value adopted for T. cruzi infection was $1 / 40$ when IFAT results for Leishmania spp were negative; in Leishmania spp.-positive dogs, positive T. cruzi infection was considered only when the IFAT titer was $\geq 1 / 80$ [50].

\section{Geospatial analysis}

The map of BITER bases was acquired from the National Administrative Department of Statistics (MG-DANE) (https://geoportal.dane.gov.co/servicios/descarga-ymetadatos/descarga-mgn-marco-geoestadistico-Nacio nal/). All biological data coordinates were captured using a hand-held Global Positioning System (GPS) and recorded in the World Geodetic System 1984 (WGS 84 Datum) geodetic coordinate system. We analyzed the spatial distribution of T. cruzi-infected triatomines and mammals inside military installations, and hotspots of potential transmission were geolocated and generated with the QGIS 3.10.9 program [51].

\section{Data analysis}

The statistical association between the number of Rhodnius pallescens collected, seasonality (rainy or dry season) and infection rate comparisons were performed using the chi-square test with a $P<0.05$ considered to be significant. Data analyses were performed using SPSS version 18.0 statistical software (SPSS, IBM Corp., Armonk, NY, USA).

\section{Results}

\section{Entomological survey, T. cruzi infection rate} and blood-meal sources

A total of 86 triatomine bugs were collected in three of four BITER locations evaluated during this study, all in palms and wooded areas (Table 1). The species captured were mostly $R$. pallescens $(95.3 \%, n=82)$, followed by Rhodnius prolixus $(2.3 \%, n=2)$, Triatoma dimidiata $(1.2 \%, n=1)$ and Triatoma maculata $(1.2 \%, n=1)$. No triatomines were found inside bedrooms or lodgings. 


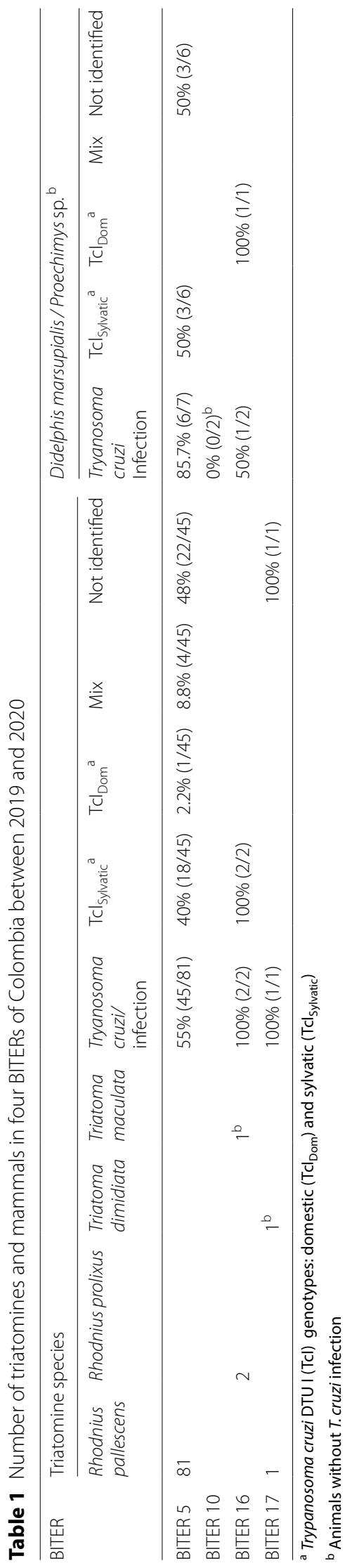


However, one $R$. pallescens and one $T$. dimidiata were collected by military personnel in BITER 17 (Carepa) in the wooded area. All triatomines collected in palms were located between 3 and 10 meters from the kitchen and bedrooms in BITER 5 (Aguachica) and BITER 16 (Yopal).

Triatomines were found to be most abundant in BITER 5 (Aguachica), where we collected $97 \%$ of all $R$. pallescens collected in the study (Table 1 ). Of the $81 R$. pallescens collected in BITER, 30 and 51 were collected during the rainy and dry seasons, respectively. All bugs captured in the rainy season were in the nymphal state, while $70 \%$ $(36 / 51)$ of insects collected in the dry season were adults. The T. cruzi infection rate was higher in triatomine bugs collected in the dry season when compared to those collected in the rainy one $\left(X^{2}=30.22, P<0.0001\right)$.

All captured triatomines were evaluated for the presence of $T$. cruzi. Of the $R$. pallescens collected, $56.1 \%$ ( $n=46 / 82$ ) were positive for $T$. cruzi by the PCR analysis. Two $R$. prolixus were collected, both of which were also infected $100 \%$ (2/2). Conversely, $T$. dimidiata and $T$. maculata were not infected (Table 1). TcI genotype was found in all of the $R$. pallescens and $R$. prolixus positive samples corresponding to $57.1 \%(48 / 84)$, with $\mathrm{TcI}_{\text {Sylvatic }}$ detected in $41.7 \%(20 / 48)$, TcI Dom detected in $2.1 \%(1 / 48)$ and $\mathrm{TcI}_{\text {Dom }} / \mathrm{TcI}$ Sylvatic detected in $8.3 \%(4 / 48)$. It was not possible to genotype $47.9 \%(23 / 48)$ of the samples (Table 1).

A total of eight feeding sources were found in 40 specimens of $R$. pallescenses and two of $R$. prolixus. These sources included $D$. marsupialis (opossum) (59.5\%, 25/42), Homo sapiens (human) $(26.2 \%, 11 / 42)$ and other species $(14.3 \%, 6 / 42)$ : Metachirus nudicaudatus, Mus musculus, Philander oposum,. Caracara cheriway, a member of the Cricetidae Family and one individual of the Didelphimorphia Order. Both $R$. prolixus samples evaluated had fed on Homo sapiens. All triatomines of both species that had fed on humans were positive for $T$. cruzi, and the only species feeding on birds was also positive for this parasite.

\section{Trypanosoma cruzi infection in synanthropic mammals}

Eleven synanthropic mammals were captured, nine $D$. marsupialis and two Proechimys semispinosus (Table 1). Seven D. marsupialis were captured in BITER 5 (Aguachica), 85\% (6/7) of these were positive by molecular detection and hemoculture. The remaining two were captured in BITER 16 (Yopal), one of which was positive by both tools. Only TcI was found in this species. Concerning TcI genotypes, we detected sylvatic TcI in $50 \%$ (3/6), and TcI Dom in 16.6\% (1/6). However, the $33.3 \%$ left $(2 / 6)$ could not be typed (Table 1$)$. Finally, P. semispinosus were not infected.

\section{T. cruzi infection in working and creole dogs}

A total of 33 working military dogs (17 male (51\%), 16 female (49\%)) and 19 creole dogs, present for more than 1 year in the establishments according to the militarystaff reports, were evaluated. Of the 33 working dogs, 16 had previously participated in activities involving narcotics and/or explosives detection, while 17 were still being trained and had never been in operational areas. Their age ranged from approximately 8 months to 5 years (median age: 4.5 years). The most common breed was Labrador $(n=22)$, followed by Dutch shepherd $(n=7)$, Belgian shepherd $(n=3)$ and Golden retriever $(n=1)$. The 19 creole dogs ( $74 \%$ male, $16 \%$ female; all adult dogs) consisted of stray dogs that were residents of municipalities near the respective BITER. These dogs entered the battalion locations in search of food and were subsequently adopted (Table 2).

Of the 52 dogs sampled, five $(9.6 \%, 95 \%$ confidence interval 95\% 3.20-21.03) were seropositive based on two independent tests. Four of the dogs testing positive were creole, with the following distribution: three from BITER 5 (Aguachica) and one from BITER 16 (El Yopal). The one seropositive working dog was detected in BITER 17 (Carepa) and has served in explosive detection activities inside the operational area. No infection was detected in the dogs from BITER 10 (La Loma) (Table 2). Molecular diagnosis of blood samples stored in guanidine chloride buffer (BCG), which amplified the satellite DNA of $T$. cruzi, did not show the presence of parasites in the 52 dogs evaluated.

\section{Geospatial analysis}

Analysis of the generated maps showed areas inside the battalions with a greater risk of transmission due to the abundance of infected triatomines and synanthropic mammals (Fig. 2). The presence of infected $R$. pallescens that fed on human blood and of infected $D$. marsupialis near the lodgings and kitchens suggests a potential risk of vectorial and oral transmission of T. cruzi in BITER 5 (Aguachica) and BITER 16 (Yopal). A lower potential risk was observed in BITER 10 (La Loma), where infected

Table 2 Frequency of seropositivity with T. cruzi in military working dogs and creole dogs in four BITERs in three municipalities of Colombia between 2019 and 2020

\begin{tabular}{lll}
\hline Municipalities (BITER) & $\begin{array}{l}\text { Working dogs, sample } \\
\text { size (seropositive \%) }\end{array}$ & $\begin{array}{l}\text { Creole dogs, sample } \\
\text { size (seropositive \%) }\end{array}$ \\
\hline Aguachica (BITER 5) & $2(0 \%)$ & $7(43 \%)$ \\
El Yopal (BITER 16) & $2(0 \%)$ & $7(14 \%)$ \\
Carepa (BITER 17) & $29(3.44 \%)$ & 0 \\
La Loma (BITER 10) & 0 & $5(0 \%)$ \\
Total & $3.03 \%$ & $21.05 \%$ \\
\hline
\end{tabular}



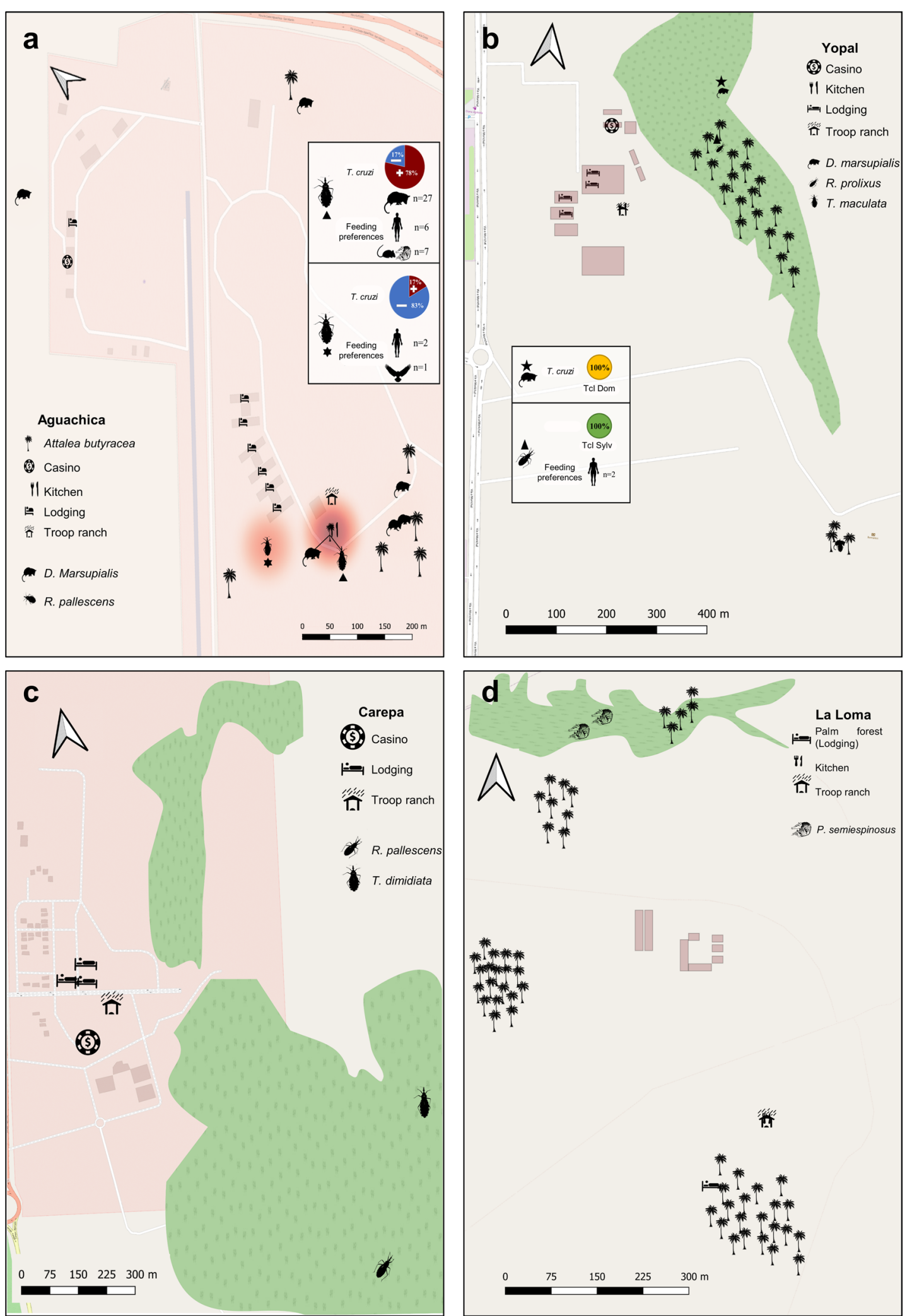

Fig. 2 Geospatial distribution of triatomines and host (infected and not infected) in four BITER battalions in Colombia. a BITER 5 (Aguachica), b BITER 16 (Yopal), c BITER 17 (Carepa), d BITER 10 (La Loma). Maps were prepared using shapefiles from OpenStreetMap Standard 
triatomine bugs were not found near the location, and BITER 5, where no T. cruzi infections were found in synanthropic mammals (Fig. 2).

\section{Discussion}

The success of the Southern Cone Initiative (INCOSUR), which achieved the elimination of T. infestans in many areas and the elimination of $R$. prolixus in some Central America countries and some Colombian municipalities, is important in terms of the significant advances in $C D$ control $[52,53]$. However, the enzootic or sylvatic cycle in triatomines across all continents, together with the wide distribution of household-invading triatomines, is now responsible for most CD transmission in countries like Brazil, Argentina, Colombia and Nicaragua $[14,17,18,31,32]$. A scenario where the restriction of a given multi-host parasite based on the control of one single vector species will always be insufficient because parasite transmission rarely relies on a single system [27, 54]. Therefore, the sustainability of successful control strategies for $\mathrm{CD}$ requires more accurate knowledge of environmental factors that underlie the enzootic transmission cycle of this parasite [55]. In Colombia, aspects determining the current epidemiology of $C D$ are still unknown, and the potential risk of enzootic transmission inside overcrowded settlements and installations, such as work camps or military barracks, located in endemic areas has not been explored. Here we described the potential risk for spillover infections in the military population by a well-established T. cruzi enzootic cycle due to: (i) a high rate of T. cruzi infection of triatomine bugs collected; (ii) increased contact between T. cruzi-infected triatomines and humans according to blood source analysis; (iii) selection and dominance of mammalian species with high competence for being a reservoir; and (iv) close proximity of infected triatomines and infected $D$. marsupialis to accommodations and kitchens (Table 1; Fig. 2).

Determining the spatial distribution of the elements that form this epidemiological chain in the enzootic cycle and suitable contact with humans are of pivotal importance for determining trends and risk evaluation. The present study was developed in four BITERs located in four municipalities with historical reports of infected triatomine bugs [36, 37]. However, differences in potential risk intensities of $T$. cruzi transmission were found at these locations. BITER 10 (La Loma) and 17 (Carepa) could be considered to have a lower potential risk of $T$. cruzi transmission, while BITER 5 (Aguachica) and 16 (Yopal) display comparable patterns regarding the presence of naturally T. cruzi-infected $R$. pallescens and $R$. prolixus, respectively. These patterns include the positive selection of generalist mammal species with high transmissibility competence, such as D. marsupialis. These eco-epidemiological characteristics could increase the opportunities for contact between humans, domestic animals and the sylvatic cycle. These findings in BITERs with a higher potential risk are in accordance with the epidemiological situation reported by the SIVIGILA for these areas (Fig. 1) and agree with previous outbreaks of $\mathrm{CD}$ caused by oral transmission due to spillover of the enzootic cycle described in recent years in the municipalities of Aguachica, Yopal and Paz de Ariporo (Casanare) [18, $56,57]$.

BITER 5, located in Aguachica municipality in the Caribbean region of Colombia, presents an epidemiological profile that enhances the chances of transmission to humans, thereby representing a potential risk for around 30,000 active members of the National Army who participate in training and re-training activities each year. The results of this study show a close proximity between the enzootic transmission cycle and the quartered population. Molecular analysis supports the notion that $R$. pallescens actively participates in the enzootic transmission, showing the high-frequency infection with the $\mathrm{TcI}_{\text {Sylvatic }}(46.8 \%)$ genotype and the high frequency of feeding on $D$. marsupialis (66\%) and other sylvatic mammals. However, the presence of human blood in $18.6 \%$ of the analyzed insects and $11.45 \%$ infection with $\mathrm{TcI}_{\text {Dom }}$, reveal an active interplay between sylvatic and domestic transmission, as previously reported in other regions of Colombia [18]. The same ecological situation was found in BITER 16 where we found $R$. prolixus in A. butyracea palms infected with $\mathrm{TcI}_{\text {Sylvatic }}$ that fed on human blood, which can lead to a potential risk of T. cruzi transmission to more than 30,000 active members present in the Orinoco region. These findings are in agreement with those of previous studies and support the premise that in Colombia there is a high risk of $R$. pallescens intrusion supported by the high presence blood-feeding on humans and T. cruzi infection [18].

The spatial convergence found in the BITER 5 location facilitates triatomines reaching human installations by being attracted by artificial light in the search of food $[17,58]$. A similar eco-epidemiological situation has been described in some regions of Colombia and Panama where this species has been found to be a T. cruzi vector $[16,38,59,60]$. The higher number of triatomines found in the dry season added to the higher infection rates in this season, increasing the risk of an oral outbreak in this period $[17,18,56]$. These ecological characteristics reveal the ability of $R$. pallescens to participate in complex transmission dynamics that may exhibit local peculiarities and lead to the emergence or re-emergence of outbreaks.

On the other hand, the dominance of D. marsupialis with high transmissibility, as shown by hemoculture, 
supports the high potential risk inside BITER 5 and 16 . The reduced diversity and the selection of suitable reservoir hosts of T. cruzi have been reported as common traits and possible factors related to human outbreaks by the oral route $[27,54]$. In these military installations, the sympatry of the common opossum $R$. pallescens and $R$. prolixus and humans near the kitchen enhanced the risk of oral transmission through the consumption of food or juices contaminated by triatomine feces or food/beverages contaminated with animal secretions that contain metacyclic trypomastigotes [32, 61, 62]. The outbreaks due to accidental food contamination in these BITERs would be challenging to manage due to the large number of people affected. Future studies should include highresolution molecular tracking to unravel the transmission dynamics of T. cruzi infection within these settlements.

BITER 17 and 10, located in Carepa (Antioquia) and La Loma (Cesar), respectively, were found to have the lowest potential risk of $C D$ transmission. In the Uraba region of BITER 17, we collected only two triatomine bugs: one infected $R$. pallescens and one non-infected T. dimidiata. Contrary to BITER 5 and 16, triatomines captured in this BITER were found by military personnel in forest areas far away from the installations inhabited by military personnel (Fig. 2). These results show the existence of enzootic transmission with $R$. pallescens. Regarding $T$. dimidiata, metapopulations of this species distributed in the Urabá region are considered to be of low epidemiologic relevance $[63,64]$. Finally, we believe that we did not capture mammals inside this military installation due to the ready availability of banana crops around the BITER [65]. All these factors support a low potential risk of $T$. cruzi in this area.

In addition, no triatomine bug was collected in BITER 10 , and even the two potential reservoirs (P. semiespinosus) collected there were not infected [55]. BITER 10 is in La Loma, a rural area of the municipality of La Jagua de Ibirico (Cesar), a zone with a high abundance of $A$. butyracea palms and reports of vectors, such as $R$. pallescens, Erathyrus cuspidatus and T. dimidiata with their ecotopes in this palm species [36, 37]. Our results show the absence of triatomine bugs in palms near the bedrooms and kitchen of BITER 10, but the enzootic cycle could be happening in palms forest not included in the present study. However, it is necessary to mention that BITER 10 is in an area of high mining exploitation and accelerated desertification processes where environmental characteristics, such as vapor pressure, can affect the abundance of stenohydric species like $R$. pallescens $[65,66]$. We suggest that both hypotheses should be evaluated in the future studies.

The serological evaluation of the working dogs showed that one of the working military dogs was infected with T. cruzi. In the Colombian National Army the function of the guard dog is fundamental for troop protection in mission activities, where both soldiers and guard dogs remain for long periods within sylvatic areas. These activities have been related to the infection of working army dogs with canine cutaneous leishmaniasis in Colombia [60]. To our knowledge, few studies have explored the CD infection levels in dogs of Latin America. Here, we reported a T. cruzi infection in military working dogs of Colombia. However, the epidemiological relevance and the veterinarian importance of infected dogs should be determined in the future. Finally, the presence of infected stray dogs inside the studied BITER is a finding that draws our attention due to the known role of domestic dogs as synanthropic reservoirs that could generate new transmission foci inside BITERs [67-70].

There are some limitations to the present study. First, the results are not supported by a seroprevalence study in the military population present in the four BITERs evaluated. This aspect could be considered in the future. Second, Colombia's National Army has 14 BITERs, with many located in municipalities with ecological conditions for T. cruzi transmission and other pathogens transmitted by insects, such as leishmaniasis, malaria and dengue. We did not include these BITERs in the present study nor did we assess the risk of infection of other diseases transmitted by insects. Future studies should expand the number of BITERS included in the analysis.

This study provides new insightful information on $T$. cruzi transmission dynamics and the potential risk of oral transmission in an area with non-domiciled vectors in some locations in Colombia, including the presence of triatomines adapted to A. butyracea forests and coexisting with synanthropic mammal reservoirs as $D$. marsupialis. These scenarios require an alternative eco-health (One Health) approach for reducing human-triatomine bugs and human $-D$. marsupialis contact through: (i) the managing the environment by eliminating palms near lodgings and kitchens; (ii) proper care of area inside battalion or cantonment centers; and (iii) proper waste management. Finally, it is necessary to achieve active community participation with the military population, an entomological surveillance program led by the staff of each battalion and health educational during the training and re-training activities as a sustainability strategy including regular testing for $\mathrm{CD}$.

\section{Conclusions}

In conclusion, we present a study in four training and re-training battalions (BITERs) where around 100,000 active Colombian military troops receive training over 
the years. The evaluation of T. cruzi natural infection in mammals, added to the identification of blood-meal sources in triatomine bugs, genotyping of $T$. cruzi and results of the spatial analysis, provide a better understanding of the parasite's spillover process and potential risk of infection for the military population inside these military camps. The same scenario may be relevant to other military establishments of Colombia and other endemic countries. Therefore, these conditions should be evaluated in all military and working camps located in endemic areas. Future serological and molecular studies among military population in BITERs with the highest potential risk should be carried out to establish in deeper detail the extent of human infection and the circulation of $T$. cruzi in light of the findings of the present study.

\begin{abstract}
Abbreviations
BCG: Guanidine hydrochloride buffer; BCEl: Grupo Biología y Control de Enfermedades Infecciosas; BITER: Battalion of Instruction, Training en Retraining; BLASTn: Basic local alignment search tool for nucleotide databases: CD: Chagas disease; CIMBIUR: Centro de Investigaciones en Microbiología y Biotecnología de la Universidad del Rosario; ExoSAP-IT: Exonuclease I and shrimp alkaline phosphatase; DTU: Discrete typing unit; ELISA: Enzyme-linked immunosorbent assay; GINETEJ: Grupo de Investigación en Enfermedades Tropicales del Ejército; IFAT: Indirect immunofluorescence antibody test; INCOSUR: Southern Cone Initiative; GPS: Global Positioning System; IgG: Immunoglobulin G; MG-DANE: National Administrative Department of Statistics; NCBI: National Center for Biotechnology Information; rRNA: Ribosomal ribonucleic acid; SL-IR: Spliced leader intergenic region; SIVIGILA: National Public Health Surveillance System; Tcl: Trypanosoma cruzi DTU I;WGS: World Geodetic System.
\end{abstract}

\section{Supplementary Information}

The online version contains supplementary material available at https://doi. org/10.1186/s13071-021-05018-4.

Additional file 1: Appendix S1. Primers and thermal profiles condition for the genotyping of T. cruzi.

Additional file 2: Figure S1. Algorithm of T. cruzi genotyping in positive samples.

\section{Acknowledgements}

We thank Dirección de Ciencia y Tecnología (DITEC) of the Colombian National Army for its support in the processes, resource management, and permanent advice. OCB was supported by a fellowship from MINCIENCIAS.

\section{Authors' contributions}

OCB and CM conceived and designed the study. YR, CACC, OR, MTA and CM managed the funding acquisition and formulated the needs plan for the research project subjected to the current study. OCB, JT, SZ and CM participated in the collection and storage of samples. OCB, CH, SZ, YR, CACC and JDR conducted serological and molecular tests. OCB, YR, CH, SZ, GH and JDR analyzed the data. OCB, GH and JDR conducted the spatial analysis. OCB, JDR and $C M$ wrote the original draft of the manuscript. OCB, CACC, JDR and CM reviewed and edited the written manuscript. All authors read and approved the final version of the manuscript.

\section{Funding}

This article was funded by Dirección de Ciencia y Tecnología (DITEC) of the Comando de Educación y Doctrina (CEDOC), Colombia National Army for the execution of the research project, through royalties for agreements with hydrocarbon companies such as C.N.R COLOMBIAN NATURAL RESOURCES I S.A.S, CONOCOPHILLIPS COLOMBIA VENTURES LTD, SOCIEDAD MINERA DE SANTANDER S.A.S., PROMIGAS S.A. and QUINTANA S.A.S. The authors deeply thank Springer Nature waivers team for Publication Fee Grant MS 9079572032042290 of USD 2590.00 (100\% discount). The commercial funders played no role in the study design, data collection, data analysis, decision to publish and writing of the manuscript.

\section{Availability of data and materials}

All data sets used or analysed in the current study are included in the supplementary information files of this published article. All genetic sequences derived of current study are deposited and available in GenBank (https:/ www . ncbi.nlm.nih.gov/genbank/) under accession numbers OK040172 - OK040196 and OK058390 - OK058403.

\section{Declarations}

Ethical approval and consent to participate

All animals were handled by a military medical veterinarian strictly according to good animal practices as defined by the Colombian code of practice for the care and use of animals for scientific purposes, established by law 84 of 1989. Ethical approval (Act No 113 of 2017). Permission for analyzing animal species was obtained from the animal ethics committee of the Universidad de Antioquia.

\section{Consent for publication}

Not applicable.

\section{Competing interests}

The authors declare that they have no conflict of interests. The findings and conclusions in this manuscript are those of the authors and do not necessarily represent Colombian National Army.

\section{Author details}

${ }^{1}$ Grupo de Investigación en Enfermedades Tropicales del Ejército (GINETEJ), Laboratorio de Referencia E Investigación, Dirección de Sanidad Ejército, Bogotaá, Colombia. ${ }^{2}$ Centro de Investigaciones en Microbiología y BiotecnologíaUR (CIMBIUR), Facultad de Ciencias Naturales, Universidad del Rosario, Bogotá, Colombia. ${ }^{3}$ Centro de Tecnología en Salud (CETESA), Innovaseq SAS, Bogotá, Colombia. ${ }^{4}$ Grupo Biología Y Control de Enfermedades Infecciosas (BCEI), Universidad de Antioquia, Calle 70 No. 52-21, Medellín, Colombia.

Received: 11 May 2021 Accepted: 14 September 2021

Published online: 09 October 2021

\section{References}

1. World Health Organization. Chagas disease in Latin America: an epidemiological update based on 2010 estimates. Wkly Epidemiol Rec. 2015;90:33-43.

2. Olivera MJ, Fory JA, Porras JF, Buitrago G. Prevalence of Chagas disease in Colombia: a systematic review and meta-analysis. PLoS ONE. 2019;14(1):e0210156.

3. Chagas C. Nova tripanozomiaze humana: estudos sobre a morfolojia e o ciclo evolutivo do Schizotrypanum cruzi n. gen., n. sp., ajente etiolojico de nova entidade morbida do homem. Memórias do Instituto Oswaldo Cruz. 1909;1:159-218.

4. World Health Organization, UNICEF/UNDP/World Bank/WHO Special Programme for Research and Training in Tropical Diseases \& Pan American Health Organization. Reporte del grupo de trabajo científico sobre la enfermedad de Chagas : 17-20 de abril de 2005, actualizado en julio de 2007, Buenos Aires, Argentina. Editado por Felipe Guhl y Janis K. LazdinsHelds. WHO. https://apps.who.int/iris/handle/10665/69724. Accessed 13 Mar 2020.

5. Zingales B, Andrade SG, Briones MR, Campbell DA, Chiari E, Fernandes O, et al. A new consensus for Trypanosoma cruzi intraspecific nomenclature: second revision meeting recommends TcI to TcVI. Mem Inst Oswaldo Cruz. 2009;104(7):1051-4. 
6. Marcili A, Lima L, Cavazzana M, Junqueira AC, Veludo HH, Maia Da Silva $F$, et al. A new genotype of Trypanosoma cruzi associated with bats evidenced by phylogenetic analyses using SSU rDNA, cytochrome $b$ and Histone $\mathrm{H} 2 \mathrm{~B}$ genes and genotyping based on ITS1 rDNA. Parasitology. 2009;136(6):641-55.

7. Cura Cl, Mejía-Jaramillo AM, Duffy T, Burgos JM, Rodriguero M, Cardinal MV, et al. Trypanosoma cruzi I genotypes in different geographical regions and transmission cycles based on a microsatellite motif of the intergenic spacer of spliced-leader genes. Int J Parasitol. 2010;40(14):1599-607.

8. Ramírez JD, Guhl F, Messenger LA, Lewis MD, Montilla M, Cucunuba Z, et al. Contemporary cryptic sexuality in Trypanosoma cruzi. Mol Ecol. 2012;21(17):4216-26.

9. Leon CM, Hernandez C, Montilla M, Ramirez JD. Retrospective distribution of Trypanosoma cruzi I genotypes in Colombia. Mem Inst Oswaldo Cruz. 2015;110(3):387-93.

10. Ramírez JD, Hernández C. Trypanosoma cruzi l: towards the need of genetic subdivision? Part II Acta Trop. 2017;2018(184):53-8.

11. Noireau F, Dujardin J. Biology of Triatominae. In: Telleria J, Tibayrenc M, editors. American trypanosomiasis Chagas disease one hundred years of research. Amsterdam: Elsevier; 2010. p. 149-68.

12. Coura JR, Viñas PA, Junqueira ACV. Ecoepidemiology, Short history and control of chagas disease in the endemic countries and the new challenge for non-endemic countries. Mem Inst Oswaldo Cruz. 2014;109(7):856-62

13. Guhl F. Chagas disease in Andean countries. Mem Inst Oswaldo Cruz. 2007;102(Suppl):29-38.

14. Gorla D, Noireau F. Geographic distribution of Triatominae vectors in America. In: In: Telleria J, Tibayrenc M, editors. American trypanosomiasis Chagas disease. Amsterdam: Elsevier; 2017. p. 197-221.

15. Hashimoto K, Cordon-Rosales C, Trampe R, Kawabata M. Impact of single and multiple residual sprayings of pyrethroid insecticides against Triatoma dimidiata (Reduviiade; Triatominae), the principal vector of Chagas disease in Jutiapa, Guatemala. Am J Trop Med Hyg. 2006;75(2):226-30.

16. Guhl F, Pinto N, Aguilera G. Sylvatic triatominae: a new challenge in vector control transmission. Mem Inst Oswaldo Cruz. 2009;104(Suppl 1):71-5.

17. Cantillo-Barraza O, Chaverra D, Marcet P, Arboleda-Sánchez S, TrianaChávez O. Trypanosoma cruzi transmission in a Colombian Caribbean region suggests that secondary vectors play an important epidemiological role. Parasit Vectors. 2014;7(1):1-10

18. Hernández C, Salazar C, Brochero H, Teherán A, Buitrago LS, Vera M, et al. Untangling the transmission dynamics of primary and secondary vectors of Trypanosoma cruzi in Colombia: parasite infection, feeding sources and discrete typing units. Parasit Vectors. 2016;9(1):1-12.

19. de Arias AR, de la Fuente ALC, Gómez A, Cecere MC, Rolán M, Gómez $M C V$, et al. Morphometric wings similarity among sylvatic and domestic populations of Triatoma infestans (Hemiptera: Reduviidae) from the Gran Chaco region of Paraguay. Am J Trop Med Hyg. 2017;97(2):481-8.

20. Ribeiro G, Dos Santos CGS, Lanza F, Reis J, Vaccarezza F, Diniz C, et al. Wide distribution of Trypanosoma cruzi-infected triatomines in the State of Bahia, Brazil. Parasit Vectors. 2019;12(1):604.

21. Cardinal MV, Sartor PA, Gaspe MS, Enriquez GF, Colaianni I, Gürtler RE. High levels of human infection with Trypanosoma cruzi associated with the domestic density of infected vectors and hosts in a rural area of northeastern Argentina. Parasit Vectors. 2018;11(1):1-13.

22. Rodríquez-Planes LI, Gaspe MS, Enriquez GF, Gürtler RE. Habitat-specific occupancy and a metapopulation model of Triatoma sordida (Hemiptera: Reduviidae), a secondary vector of Chagas disease, in northeastern Argentina. J Med Entomol. 2018;55(2):370-81.

23. Crocco L, Nattero J, López A, Cardozo M, Soria C, Ortiz V, et al. Factors associated with the presence of triatomines in rural areas of south Argentine Chaco. Rev Soc Bras Med Trop. 2019;52:e20180357.

24. Ihle-Soto C, Costoya E, Correa JP, Bacigalupo A, Cornejo-Villar B, Estadella $V$, et al. Spatio-temporal characterization of Trypanosoma cruzi infection and discrete typing units infecting hosts and vectors from non-domestic foci of Chile. PLoS Negl Trop Dis. 2019;13(2):e0007170.

25. Cantillo-Barraza O, Medina M, Zuluaga S, Valverde C, Motta C, Ladino $\mathrm{A}$, et al. Eco-epidemiological study reveals the importance of Triatoma dimidiata in the Trypanosoma cruzi transmission, in a municipality certified without transmission by Rhodnius prolixus in Colombia. Acta Trop. 2020;209:105550
26. Patz JA, Graczyk TK, Geller N, Vittor AY. Effects of environmental change on emerging parasitic diseases. Int J Parasitol. 2000;30(12-13):1395-405.

27. Roque AL, Xavier SC, Gerhardt M, Silva MF, Lima VS, D'Andrea PS, et al. Trypanosoma cruzi among wild and domestic mammals in different areas of the Abaetetuba municipality (Pará State, Brazil), an endemic Chagas disease transmission area. Vet Parasitol. 2013;193(1-3):71-7.

28. Xavier SC, Roque AL, Lima VS, Monteiro KJ, Otaviano JC, da Silva LF, et al. Lower richness of small wild mammal species and chagas disease risk. PLoS Negl Trop Dis. 2012;6(5):e1647.

29. Hernández C, Vera MJ, Cucunubá Z, Flórez C, Cantillo O, Buitrago LS, et al. High-resolution molecular typing of Trypanosoma cruzi in 2 large outbreaks of acute Chagas disease in Colombia. J Infect Dis. 2016;214(8):1252-5.

30. Rueda K, Trujillo JE, Carranza JC, Vallejo GA. Oral transmission of Trypanosoma cruzi: a new epidemiological scenario for Chagas' disease in Colombia and other South American countries. Biomedica. 2014;34(4):631-41.

31. Guhl F, Ramírez JD. Poverty, migration, and Chagas disease. Curr Trop Med Rep. 2021:8:1-7.

32. Velásquez-Ortiz N, Ramírez JD. Understanding the oral transmission of Trypanosoma cruzi as a veterinary and medical foodborne zoonosis. Res Vet Sci. 2020;132:448-61.

33. Instituto Nacional de Salud. Sistema Nacional de Vigilancia en Salud Pública (SIVIGILA), INS, Ministerio de Salud y Protección Social. Notificaciones por evento: Enfermedad de Chagas en Fuerzas Militares. http:// portalsivigila.ins.gov.co/. Accessed 13 Mar 2020.

34. Nicholls RS, Cucunubá ZM, Knudson A, Flórez AC, Montilla M, Puerta $\mathrm{CJ}$, et al. Acute Chagas disease in Colombia: a rarely suspected disease. Report of 10 cases presented during the 2002-2005 period. Biomedica. 2007;27(Suppl 1):8-17.

35. Méndez C, Duque MC, Romero Y, Pérez J, Rodríguez O, Correa-Cárdenas CA, et al. Prevalence of Trypanosoma cruzi infection in active military population of the Colombian National Army gathered in five departments. PLoS ONE. 2019;14(10):e223611.

36. Guhl F, Aguilera G, Pinto N, Vergara D. Updated geographical distribution and ecoepidemiology of the triatomine fauna (Reduviidae: Triatominae) in Colombia. Biomedica. 2007;27(Suppl 1):143-62.

37. Parra-Henao G, Angulo VM, Osorio L, Jaramillo-O N. Geographic distribution and ecology of Triatoma dimidiata (Hemiptera: Reduviidae) in Colombia. J Med Entomol. 2016;53(1):122-9.

38. Romana CA, Pizarro JC, Rodas E, Guilbert E. Palm trees as ecological indicators of risk areas for Chagas disease. Trans R Soc Trop Med Hyg. 1999;93(6):594-5.

39. Lent H, Wygodzinsky P. Revision of the Triatominae (Hemiptera, Reduviidae), and their significance as vectors of Chagas disease. Bull Am Mus Nat Hist. 1979;163:123-520.

40. Moser DR, Kirchhoff LV, Donelson JE. Detection of Trypanosoma cruzi by DNA amplification using the polymerase chain reaction. J Clin Microbiol. 1989;27(7):1477-82.

41. Botero LA, Mejía AM, Triana O. Caracterización biológica y genética de dos clones pertenecientes a los grupos I y || de Trypanosoma cruzi de Colombia. Biomédica. 2007;27(esp1):64.

42. Hernández C, Cucunubá Z, Flórez C, Olivera M, Valencia C, Zambrano P, et al. Molecular diagnosis of Chagas disease in Colombia: parasitic loads and discrete typing units in patients from acute and chronic phases. PLoS Negl Trop Dis. 2016;10(9):1-20.

43. Sambrook J, Fritsch EF, Maniatis T. Molecular cloning: a laboratory manual. New York: Cold Spring Harbor Laboratory; 1989.

44. Souto RP, Fernandes O, Macedo AM, Campbell DA, Zingales B. DNA markers define two major phylogenetic lineages of Trypanosoma cruzi. Mol Biochem Parasitol. 1996;83(2):141-52.

45. Ramírez JD, Guhl F, Umezawa ES, Morillo CA, Rosas F, Marin-Neto JA, et al. Evaluation of adult chronic Chagas' heart disease diagnosis by molecular and serological methods. J Clin Microbiol. 2009;47(12):3945-51.

46. Falla A, Herrera C, Fajardo A, Montilla M, Vallejo GA, Guhl F. Haplotype identification within Trypanosoma cruzi I in Colombian isolates from several reservoirs, vectors and humans. Acta Trop. 2009:110(1):15-21.

47. Villa LM, Guhl F, Zabala D, Ramírez JD, Urrea DA, Hernández DC, et al. The identification of two Trypanosoma cruzi I genotypes from domestic and sylvatic transmission cycles in Colombia based on a single polymerase chain reaction amplification of the spliced-leader intergenic region. Mem Inst Oswaldo Cruz. 2013;108:932-5. 
48. Dumonteil E, Ramirez-Sierra M-J, Pérez-Carrillo S, Teh-Poot C, Herrera C, Gourbière $S$, et al. Detailed ecological associations of triatomines revealed by metabarcoding and next-generation sequencing: implications for triatomine behavior and Trypanosoma cruzi transmission cycles. Sci Rep. 2018:8(1):4140.

49. Kumar S, Stecher G, Li M, Knyaz C, Tamura K. MEGA X: molecular evolutionary genetics analysis across computing platforms. Mol Biol Evol. 2018:35:1547-9.

50. Cantillo-Barraza O, Garces E, Gomez-Palacio A, Cortes LA, Pereira A, Marcet PL, et al. Eco-epidemiological study of an endemic Chagas disease region in northern Colombia reveals the importance of Triatoma maculata (Hemiptera: Reduviidae), dogs and Didelphis marsupialis in Trypanosoma cruzi maintenance. Parasit Vectors. 2015;8:482.

51. QGIS Development Team. QGIS Geographic Information System v. 3.20 Odense. Open Source Geospatial Foundation Project. https://www.qgis. org/en/site/. Accessed 05 Oct 2020.

52. Moncayo A, Silveira AC. Current trends and future prospects for control of Chagas disease. In: Telleria J, Tibayrenc M, editors. American trypanosomiasis Chagas disease: one hundred years of research. Amsterdam: Elsevier; 2010. p. 55-82.

53. Cucunubá ZM, Nouvellet P, Conteh L, Vera MJ, Angulo VM, Dib JC, et al. Modelling historical changes in the force-of-infection of Chagas disease to inform control and elimination programmes: application in Colombia. BMJ Glob Heal. 2017;2(3):1-11.

54. Xavier SC, Roque AL, Bilac D, de Araujo VA, Neto SF, Lorosa ES, et al. Distantiae transmission of Trypanosoma cruzi: a new epidemiological feature of acute Chagas disease in Brazil. PLoS Negl Trop Dis. 2014;8(5):e2878.

55. Jansen AM, Rodrigues Roque AL. Domestic and wild mammalian reservoirs. In: American trypanosomiasis Chagas disease: one hundred years of research. Amsterdam: Elsevier; 2020. p. 249-76.

56. Soto H, Tibaduiza T, Montilla M, Triana O, Suárez DC, Torres Torres M, et al. Investigation of vectors and reservoirs in an acute Chagas outbreak due to possible oral transmission in Aguachica, Cesar, Colombia. Cad Saude Publica. 2014;30(4):746-56.

57. Zuleta-Duenas LP, Lopez-Quiroga AJ, Torres-Torres F, Castaneda-Porras O. Possible oral transmission of Chagas disease among hydrocarbons sector workers in Casanare, Colombia, 2014. Biomedica. 2017;37(2):218-32.

58. Jaramillo N, Schofield CJ, Gorla D, Caro-Riaño H, Moreno J, Mejía E, et al. The role of Rhodnius pallescens as a vector of Chagas disease in Colombia and Panama. Res Rev Parasitol. 2000;60(3/4):75-82.

59. Cantillo-Barraza O, Gómez-Palacio A, Salazar D, Mejía-Jaramillo AM, Calle J, Triana O. Distribution and ecoepidemiology of the triatomine fauna (Hemiptera: Reduviidae) in Margarita Island, Bolívar. Colombia Biomedica. 2010;30(3):382-9.

60. Calzada JE, Pineda V, Garisto JD, Samudio F, Santamaria AM, Saldaña A. Human trypanosomiasis in the eastern region of the Panama Province: new endemic areas for Chagas disease. Am J Trop Med Hyg. 2010;82(4):580-2.
61. Rodriguez IG, Loaiza JR. American trypanosomiasis, or Chagas disease, in Panama: a chronological synopsis of ecological and epidemiological research. Parasit Vectors. 2017;10(1):1-16.

62. Deane MP, Lenzi HL, Jansen A. Trypanosoma cruzi: vertebrate and invertebrate cycles in the same mammal host, the opossum Didelphis marsupialis. Mem Inst Oswaldo Cruz. 1984;79(4):513-5.

63. Gómez-Palacio A, Triana O, Jaramillo-O N, Dotson EM, Marcet PL. Ecogeographical differentiation among Colombian populations of the Chagas disease vector Triatoma dimidiata (Hemiptera: Reduviidae). Infect Genet Evol. 2013;20:352-61.

64. Quirós-Gómez Ó, Jaramillo N, Angulo V, Parra-Henao G. Triatoma dimidiata in Colombia: distribution, ecology and epidemiological importance. Biomedica. 2017;37(2):274-85.

65. Zeledon R. Vectores de la enfermedad de Chagas y sus características ecofisiológicas. Interciencia. 1983;8(6):384-95.

66. Arboleda S, Gorla DE, Porcasi X, Saldaña A, Calzada J, Jaramillo-O N. Development of a geographical distribution model of Rhodnius pallescens Barber, 1932 using environmental data recorded by remote sensing. Infect Genet Evol. 2009;9(4):441-8.

67. Vélez ID, Carrillo LM, López L, Rodríguez E, Robledo SM. An epidemic outbreak of canine cutaneous leishmaniasis in colombia caused by Leishmania braziliensis and Leishmania panamensis. Am J Trop Med Hyg. 2012;86(5):807-11.

68. Ramirez JD, Turriago B, Tapia-Calle G, Guhl F. Understanding the role of dogs (Canis lupus familiaris) in the transmission dynamics of Trypanosoma cruzi genotypes in Colombia. Vet Parasitol. 2013;196(1-2):216-9.

69. Jaimes-Duenez J, Triana-Chavez O, Cantillo-Barraza O, Hernandez C, Ramirez JD, Gongora-Orjuela A. Molecular and serological detection of Trypanosoma cruzi in dogs (Canis lupus familiaris) suggests potential transmission risk in areas of recent acute Chagas disease outbreaks in Colombia. Prev Vet Med. 2017:141:1-6.

70. Cantillo-Barraza O, Bedoya SC, Xavier SCC, Zuluaga S, Salazar B, VélezMira A, et al. Trypanosoma cruzi infection in domestic and synanthropic mammals such as potential risk of sylvatic transmission in a rural area from north of Antioquia, Colombia. Parasite Epidemiol Control. 2020;11(52):e00171.

\section{Publisher's Note}

Springer Nature remains neutral with regard to jurisdictional claims in published maps and institutional affiliations.
Ready to submit your research? Choose BMC and benefit from:

- fast, convenient online submission

- thorough peer review by experienced researchers in your field

- rapid publication on acceptance

- support for research data, including large and complex data types

- gold Open Access which fosters wider collaboration and increased citations

- maximum visibility for your research: over $100 \mathrm{M}$ website views per year

At BMC, research is always in progress.

Learn more biomedcentral.com/submissions 